\title{
Dynamic Processes of Territorial Embeddedness in International Online Fashion Retailing
}

\author{
Steve Wood*1, Neil M. Coex, Iain Watson*, Christoph Teller* \\ * Surrey Business School, Faculty of Arts and Social Sciences, University of Surrey, Guildford, \\ Surrey GU2 7XH, UK \\ × Department of Geography, National University of Singapore, 1 Arts Link, Kent Ridge, Singapore
} 117570

${ }^{1}$ Corresponding author $-\underline{\text { sm.wood } @ \text { surrey.ac.uk }}$

Accepted version forthcoming in Economic Geography - February 2019.

Please refer to the version in the journal when it is published.

\begin{abstract}
Acknowledgements
We are grateful to the executives of the five case study retailers for their participation in this research. We also appreciate the helpful comments of colleagues at the 'Revisiting Services in the Regional Economy' Special Session at the Regional Studies Association Annual Conference in 2017, at the 'Practice, Space and the Economy (Revisited)' Special Session at the $5^{\text {th }}$ Global Conference on Economic Geography, Cologne in 2018 and more recently at School of Management Seminar Series, University of Stirling when earlier versions of this paper were presented. Finally, we are thankful for the feedback of the editor, Jim Murphy, and three anonymous referees.
\end{abstract}

\begin{abstract}
Global retail expansion involves dynamic relations between retailers and variegated institutional, competitive and consumer-based demands across different spatial scales. Economic geographers have framed these processes through the inter-related concepts of territorial, network and societal embeddedness of store-based retailers, but with a neglect of online retail TNCs which might enter overseas markets with minimal risk and sunk cost. This research assesses the relevance of concepts of embeddedness in the light of virtual retail networks by assessing how knowledge from the home market mediates any perceived need to localize within host market consumer cultures and institutions to achieve legitimacy, and, in turn, whether these activities might occur as a virtual or physical process. We undertook extensive case study research within five leading international online fashion retailers headquartered in the UK, involving fifty-five semi-structured interviews with chief executives, managing-, operations-, buying- and merchandising-directors. Our findings reveal market entry to be dominated by an inward-looking societal embeddedness approach with limited investment in overseas physical infrastructure and personnel as the management of product ranges and pricing, along with merchandise fulfilment, typically reside in the home market. Yet, with international experience, we conceptualize a staged and currently limited investment in territorial embeddedness through local subsidiary offices critical to realizing network embeddedness with the fashion media and the re-organization of fulfilment within some key host countries and wider supranational regions. Such developments demand increased investment and a decentralization of authority which will, in turn, likely necessitate significant reorganization of these emergent international firms.
\end{abstract}

Key words: global retailing, online retailing, territorial embeddedness, societal embeddedness, networks, distribution

JEL codes: L81, M16, L22 
The soaring growth of online retailing is sending shockwaves across the global retail industry, profoundly affecting the geography of a US $\$ 24.9$ trillion sector that has, until recently, been most evident in extensive store networks located in close proximity to consumers and adjacent to the logistics and distribution infrastructure that service these portfolios. If we take Euromonitor data on the G8 group of eight highly industrialized economies as an example, the past decade (2008-2018) has seen store-based sales remain flat $(0.0 \%)$ while non-store sales increased by a remarkable $96.3 \%{ }^{1}$. Market analysts Statista (2018) claim that global business-to-consumer e-commerce sales in 2017 were US $\$ 1,561 \mathrm{bn}$ and are forecast to increase to US $\$ 2,590 \mathrm{bn}$ by 2022 . Fashion is the largest online retail sub-sector, accounting for $28.9 \%$ of the total market. Such developments raise significant questions for economic geographers regarding the nature of global retailing and its relationship with space and place when the physical presence of stores, infrastructure and personnel is deemed less necessary and virtual access to consumers means barriers to international growth are considerably less formidable than only five years ago.

Of course, the past two decades have seen economic geographers increasingly explore the nature, scope and impacts of the globalization of store-based retailers (Coe and Wrigley, 2018). Cross-border retailing exhibits a set of richly geographical challenges for retail transnational corporations (hereafter 'TNCs') in devising appropriate expansion forms and product ranges, as well as for host market competitors and wider institutions contemplating the implications (and appropriate regulatory responses) to such incursion. By adopting a relational-networked approach to frame these phenomena, economic geographers have developed a perspective that recognizes the influence of large retailers across space but which is also sensitive to the economic, social, and political arrangements of the places in which they are situated.

In such work, retail TNCs are characterized as having to become territorially embedded within host markets in order to gain legitimacy and manage a complex range of intra-, inter- and extra-firm relations with consumers, suppliers, local partners, regulators and finance providers (Wrigley et al., 2005). From this perspective, following market entry, transnational retailers face

\footnotetext{
${ }^{1}$ Using fixed 2017 exchange rates and constant 2017 prices sourced from Euromonitor Passport database.
} 
continuous consumer, competitive and regulatory responses, and have little alternative other than to seek to contribute actively to influencing institutional change in those host economies (Durand and Wrigley, 2009). Hitherto, however, these assessments have been disproportionately focused on large store food retailers (e.g. Lowe and Wrigley, 2010; Wood et al., 2016). Yet, such retailers have experienced slowing expansion (Burt et al., 2019) and exhibit very particular business model characteristics given their store-based and fresh food focus, emphasizing within-country sourcing and entailing significant sunk costs in store and distribution center infrastructure (Wood and Reynolds, 2014). In contrast, we observe sustained global growth of fashion retailers that typically leverage a more standardized and transferable international brand resulting in centralized (rather than localized) sourcing, modest expense related to distribution and logistical infrastructure and leased (rather than owned) store networks - all contributing to low sunk costs at the point of international market entry (Burt et al., 2016). As data on the top 250 global retailers from Deloitte (2018) underlines, apparel and accessories ('fashion') retailers exhibit an extensive global coverage, being present in an average of 26.5 countries each, compared to FMCG (Fast Moving Consumer Goods - principally food) retailers being only present in an average of 5.9 countries.

Low barriers to retail internationalization are particularly characteristic of online forms of retail distribution that permit rapid cross-border expansion (Schu, 2017; Schu and Morschett, 2017) and access to a global consumer base through virtual networks. These have been characterized as involving low risk and minimal sunk costs (Coe and Wrigley, 2018). So-called 'pure play' online retailers are increasingly pervasive and do not operate store networks, with examples including fashion merchants ASOS and Boohoo.com, as well as highly influential general merchandisers, such as Amazon and Alibaba. Meanwhile, store-based retail TNCs have made aggressive inroads into developing online capability through an omni-channel proposition for customers in three ways: the generation of their own competency in this area; via acquisition activity, such as Walmart's purchase of jet.com; and also through the use of global online marketplaces.

While information and communications technologies (ICT) are central to transferring knowledge and best practice within and beyond the retail firm (Currah and Wrigley, 2004), the implications that 'store-less' online retail business models might have for the economic geography of 
international retail expansion has received scant attention (see Foster and Graham (2017) on the issue of digital embeddedness more broadly). In particular, it is unclear the degree to which the widely accepted requirement for retailers to acquire territorial embeddedness within host markets might be considered relevant in online international retail expansion. This research seeks to contribute to this conceptual debate and specifically aims to explore how decision-making and control from the home market might intersect with any perceived need for local knowledge, physical presence and local activities focused on embedding the online retail firm within host market consumer cultures and institutions to achieve legitimacy.

In turn, we examine whether the internationalization of online fashion retailers might occur virtually and/or through a physical presence and how this balance might develop over time. Our contribution is therefore in conceptualizing a shift in the embeddedness process by online fashion retailers from one that is inward looking and highly influenced by retailers' own UK-based societal embeddedness, and dependent on leveraging their virtual network embeddedness to cross borders, towards one that progressively demands greater degrees of territorial embeddedness within overseas host markets. We draw on extensive case study research undertaken in five online fashion retail TNCs headquartered in the UK to conceptualize a staged model of increasing engagement and territorial embeddedness in host markets. However, we also observe a remaining tension evident in the widespread reluctance of senior management to meaningfully re-orientate the locus of control and decision-making away from the home market, given that strategic localization is often perceived as a risk rather than an opportunity in this context.

Our paper is organized into four main sections, as follows. First, we examine the geography of international online fashion retailing and identify a lack of theorization of the process by which such firms might invest in territorial embeddedness. Accordingly, we theorize a phased (and, at this stage in their development, likely incomplete) trend toward greater engagement with host markets by online fashion retailers. Second, we detail our research methods and provide background to our case study retailers. Third, we use insights from our interviews to examine the lowly territorially embedded model that prevails in general in online fashion retailing. Fourth, we look in dynamic 
terms at how and why greater physical and relational engagement may develop over time in such firms, though still to a far lesser degree than is associated with transnational store-based retailers.

\section{Geographies of the (Online Fashion) Retail Globalization Process}

\section{Emerging Geographies of Fashion}

Geographies of fashion retailing have historically been given only limited attention within the economic geography literature (Crewe, 2017). Yet varied research perspectives have emerged in recent years as the proliferation and influence of global retail brands have led to increasingly visible implications across networks and spaces (Pike, 2013). This has been particularly evident in the upsurge in 'fast' and 'disposable' clothing, which has resulted in distinctive sourcing networks (Tokatli, 2015) and a series of ethical challenges linked to the dissociation between the places of production and consumption (Lund-Thomsen and Lindgreen, 2014).

While the rise of online retailing and social media might have disintermediatory effects on traditional fashion retailing and simultaneously empower virtual consumer communities (Crewe, 2013), there has been an ongoing focus on the relationships of particular places with processes of fashion design, curation and retail brand development within established (and emergent) centers of fashion (Brydges and Hracs, 2018a). The exploration of the artistic and architectural iconography of places that support the consumption experience has been in evidence (Crewe, 2016). Perhaps more obviously, there has been a focus on major fashion cities to assess the creative buzz alongside the related institutional and knowledge-based underpinnings of such clusters (Jansson and Power, 2010). Recent work has also embraced research on mobilities to emphasize how second tier fashion centers are becoming increasingly viable (e.g. Leslie and Brail, 2011; Molloy and Larner, 2013) and how creative workers take advantage of temporary mobility to attend fashion shows, work with intermediaries to create an impression of presence in key markets, and exploit virtual mobility through the internet and social media (Brydges and Hracs, 2018b). In this manner then, fashion knowledge is embedded in place through buzz, tacit knowledge, localized dress practices and material objects, but 
is also to a degree 'placeless' as knowledge communicated by the traditional mass media, social media and institutionalized as assets owned by firms (Weller, 2007).

Surprisingly, there has been relatively little consideration of the geography of fashion retail expansion and certainly a neglect of framing such processes in terms of the predominant discourses within the discipline relating to embeddedness. Furthermore, with the exception of the work by Louise Crewe (2017), there has been minimal assessment of geographies of online or virtual fashion retailing.

\section{A Growing Focus on Online Retail Globalization}

While the study of retail globalization has become an established strand of economic geography, the growth of online retailing and its relationship with place remains relatively under-emphasized. Having said that, there has been recognition of the logistical and systematic challenges of merging store network operations with those of online technologies to develop a seamless omni-channel experience (Birkin et al., 2017). Indeed, nearly twenty years ago Wrigley (2000: 311), reflecting on the emergence of international online retailing, noted 'the challenge to flexibility which derives from the need to adapt organizational structures historically rooted in the physical world'. Two decades later, online cross-border expansion is characterized as 'more controllable than physical store expansion' and 'as a low-cost and low-risk method of "trying out" international markets and circumventing host economy regulatory requirements relating to the establishment of physical store networks' (Coe and Wrigley, 2018: 442).

Significant insights into the geography of online retailing have emerged within the management literature. Despite online retailing overcoming geographical boundaries by leveraging data analytics without a requirement for costly store networks, Schu and Morshett's (2017) assessment of 140 online retailers in Europe suggests patterns of market entry remain highly influenced by cultural and geographical proximity to the home market. Motivations for establishing an online store are found to be largely based on rational reasons but are also partly the product of 'mimetic isomorphism' - that is to say, mimicking the behavior of other firms (Schu, 2017). The intense speed and scale of the internationalization of online retailers is marked - something evident in 
industry research by Pitney Bowes (2017) that suggests online retailers can transcend geographical distance irrespective of their size. In particular, their survey of 1,275 retailers across eight countries suggests an ease with fulfilling orders through physical logistics infrastructure within the host market, or alternatively shipping from the home market. Yet, Treadgold and Reynolds (2017) suggest there is no clear universal model for organizing online fashion retailing. Superdry, for instance, offers $85 \%$ of merchandise on a globally consistent basis whereas ASOS exhibit a significantly tighter tailoring for individual markets and spatially variegated zonal pricing.

The sheer speed of internationalization presents significant challenges to the online retail firm as the physical infrastructure and generation of appropriate market insights can trail the deployment of relevant technology and related market access. As Schu and Morshett's (2017: 720-1) recent study concluded, online retailers that adopt a 'get-big-fast' strategy might find 'the speed of internationalization is too fast to prepare for and respond to recognized differences in distant markets.' Such findings suggest international online retail expansion is not wholly immune to the implications of geographical difference and the demands for physical infrastructure. As such, international online retailing is seen as requiring investment in the "front region" or website to ensure it is "closely tailored to the market that it serves' and thus 'reflect the interests and characteristics of different consumer groups', alongside investment in the "'back region" spaces, which are needed to sustain and fulfil B2C e-commerce orders' (Wrigley and Currah, 2006: 344-5). For traditional store-based retailers developing an online capability, these new routines and practices need to become embedded throughout the retailer's systems, requiring a challenging transfer of knowledge and technology (Appel, 2016). However, the degree of investment undertaken by international 'pure play' online retailers in the 'back office' elements of their international operations is questionable. A dependence on third party logistics firms to deal with the so-called 'last mile solution' has been identified, despite final delivery frequently proving to be the 'Achilles heel' of consumer satisfaction. Wang and Xiao (2015) devise a typology of fulfilment approaches in China noting the co-evolution of e-retailing and the parcel express industry; while omni-channel retailers can offer stores as a source of potential product pick-up and returns, pure play online retailers lack this resource. 
Perhaps related to a lack of market specific insights and infrastructure amid such rapid growth of online retailers, Schu et al. (2016) find that distance from a newly entered country to the home country slows internationalization partly due to a lack of geographic proximity which presents difficulties in using the advantages the retailer had leveraged in its home market. They also suggest that in their sample of 1,110 market entries, the process of online retail expansion reduced after a threshold of 12 countries as the most attractive markets have been entered and therefore - while entering complex markets initially provided the conditions for spreading learning - eventually the complexity becomes too extreme.

Despite some concern with online retail globalization within management studies, there has been relatively little focus on this issue through the lens of economic geography. In particular, we lack detailed research on firm-level decision making, strategies and implications as they engage with heterogeneous host markets. In the next section, we reflect on how the international retail embeddedness process has been conceptualized to date and how it might be amended in the light of online, virtual retail business models.

\section{Dynamic Processes of Retail Territorial Embeddedness}

Economic geographers have theorized the process of retail globalization predominantly from the perspective of store-based food retailing. From this standpoint, retail TNCs are challenged to become necessarily embedded and essentially networked within multiple host markets which are likely to be quite different from each other and also from the home market from which they originate. Hess (2004) delimits the notion of territorial embeddedness which was further developed in the retail context to indicate the need for international retailers to become anchored within local consumer markets and cultures, real estate markets and land-use planning systems, and logistical and supply networks (Wrigley et al., 2005). Critical to the realization of territorial embeddedness is a retail TNC's network embeddedness, given that a firm's ability to adapt to, and subsequently expand within, a host market is partly governed by its networked relationships with a wide array of other organizations, whether this is via intra-, inter- or extra- firm relations that may be either formal or informal (Hess, 2004). Inevitably, within this process of international expansion, there will be a 
degree of path dependency as a retailer naturally brings with it 'some of the social and cultural attributes that it has acquired in the process of its own evolution within the context of its home base' (Wrigley et al., 2005: 441). That is to say, societal embeddedness denotes what Hess (2004: 176) refers to as the firm's 'genetic code', which draws on both where the retailer is from but also how it responds to its home environment (Burt et al., 2017). Given the likely differences between a retailer's origin and destination region, awareness of the implications of its own engrained perceptions and behaviors are necessary to ensure appropriate adaptation. Realizing the appropriate blend of local adaptation and the utilization of proven capabilities requires the retail TNC to develop systems of managing and appraising knowledge across disparate locations to potentially develop 'hybrid' localized solutions (Lowe and Wrigley, 2010; Wood et al., 2016). This demands what Meyer et al. (2011) label 'dual embeddedness' - on the one hand, organizing their networks to exploit similarities and differences of their multiple host locations; and, on the other, at the subsidiary level, a need to balance 'internal' embeddedness within the TNC network and their 'external' embeddedness in the host market.

More recently - and building on this work - Burt et al. (2016; 2017) develop a perspective on the realization of embeddedness which is contextually sensitive both to the demands of the host market and the characteristics of the transnational retailer itself. That is to say, different processes and outcomes of societal, network and territorial embeddedness will emerge relative to the 'specificities of retail sector, retail format and governance' (Burt et al., 2017: 6). There are different demands for host market anchoring across different types of retailer and, even then, it is not always appropriate to import the retailer's accepted mode of expansion due to the heterogeneous demands of localized consumer cultures and/or business systems (e.g. Bloom and Hinrichs, 2017). For example, in contrast to food, fashion retailing requires markedly less investment in store networks due to their leasehold nature as well as reduced focus on local or regional network embeddedness in product sourcing given its reliance on global supply chains, albeit with a moderation in geographical proximity to achieve acceptable delivery times (Tokatli, 2015). Nevertheless, while noting a general ability to transfer fashion brands between geographical contexts, Frasquet et al. (2018: 4) contend there is a need to 'identify the specific consumption cultures and shopping habits that call for local 
interpretations of the brand' with subsequent adaptation to product ranges and price points to varying degrees - something irrespective of the presence of store networks. Meanwhile, for luxury fashion retailers, too much localization is viewed as compromising a powerful, global brand image (Liu et al., 2016). Such sectoral differences are likely to be even more pronounced for online fashion retailing, yet there is relatively little extant economic geography research concerning these issues.

\section{Developing our Dynamic Conceptualization of Online Retail TNC Internationalization}

The principal conceptual contribution of this paper is in developing a dynamic perspective on increasing engagement with, and embeddedness within, host markets by online retail $\mathrm{TNCs}^{2}$. Specifically in terms of the longitudinal development of embeddedness by individual retail TNCs, Coe and Lee (2013; Coe et al., 2017), chart how interaction with the requirements of host markets develops over time as the retailer itself learns and acquires new capabilities, and as the institutional and regulatory climate of the host market and wider region changes (see Dales et al. (2018) on such development). At the same time, network embeddedness deepens as inter- and extra- firm relationships with wider stakeholders mature within an overseas market context (Bloom and Hinrichs, 2017)

To the best of our knowledge, our manuscript is the first to explore the economic geographies of global online retailing through an interrogation of the ways in which firms mediate between perceived home and host market demands in terms of decision-making foci, active engagement with the host market, and the provision of physical infrastructure. Specifically, in Table 1, we identify an approach overwhelmingly dominated by retailers' perceptions of their own societal embeddedness and capitalizing opportunistically on accessing overseas customers through virtual networks rather than one that exhibits any concerted focus on, and response to, the variegated characteristics and demands of multiple host market contexts. Such arm's length retention of control is evident in the limited physical infrastructure within host markets (e.g. head offices; logistics/fulfilment facilities), a predominantly ethnocentric perspective on product ranging and pricing where the demands of the

\footnotetext{
2 A staged perspective on retail internationalization is to some extent mirrored in Dawson and Mukoyama's (2014: 19) model of increasingly sophisticated processes and forms of retail internationalization.
} 
home market principally dictate any initial response to new markets, and minimal reflection on the institutional, regulatory, competitive or wider demands of the host market structure. However, we also chart a progressive and limited shift toward investment in territorial embeddedness in markets that demonstrate significant potential and with it some softening of societal embeddedness. This sees increased investments both in physical infrastructure within host markets and experiments with strategic localization.

Our conceptualization maps a progression from 'exploring online potential through the lens of societal embeddedness' with standardized global online sites, to 'exploiting the overseas host market at-a-distance' through decision-making from the home market with some limited strategic localization and then 'partial investment in territorial embeddedness through limited host market infrastructure' via the establishment of fulfilment facilities and country head offices as well as some product range and price localization. Such knowledge allows us to critically assess the continued relevance of theories of embeddedness that are readily employed within economic geography now in the light of virtual business models.

\footnotetext{
** Table 1 about here **
}

\section{Methodological Approach and Background to the Case Study Online Retail TNCs}

Conscious of some limitations highlighted by commentators of single firm case studies ( $c f$. Tokatli, 2015), our sample of firms consists of five leading international online fashion retailers based in the UK (see Table 2). The retailers were selected based on their international coverage, the online focus of their operations, and our desire for a variety of retailer sizes, business models and consumer foci. While the solely UK-based nature of our sample might be considered a limitation of our study, it was selected because it is at the vanguard of online fashion retail, with Statista (2018) calculating it was the largest fashion e-commerce market in Europe, claiming $26.8 \%$ of the market and US\$24.7bn of sales in 2017. More pragmatically, the geographical focus also reflects where the research team was based and had relevant industry contacts. 
We conducted 55 interviews with chief executives, managing directors, operations-, buyingand merchandising- directors within these organizations between 2015-2018 ${ }^{3}$. Our interviews were semi-structured so necessarily flexible and focused on a number of themes that emerged from a literature search prior to fieldwork. These interview questions focused on the retailers' processes for embracing internationalization and their associated practices particularly relating to pricing, promotion, sourcing, logistics, consumer insight and product ranging, as well as issues of decisionmaking and control. In doing so, our approach promotes an understanding of 'organisational globalisation' that takes seriously firm-level micro-scale practices (Jones and Murphy, 2010). We achieve access to these practices within the retail firms primarily through these semi-structured interviews but our conceptualization is also informed and calibrated by one of our research team (who is an active retail consultant) and, following our interviews, subsequently provided consultancy advice to the firms which served to deepen our insights - a process which also ensured we gained excellent levels of access. Both the variation of retailers in our sample and the multiple actors consulted at various hierarchies within each firm allow us to overcome many of the potential limitations of the 'close dialogue' approach identified by Clark (1998) - particularly related to issues of corporate seduction by charismatic elites - but which also allows us to assess the manner in which practices (and how any shared understanding those practices) might be shared throughout the retail TNCs in question.

Of course, while our study is focused on international online fashion retailers and concerned with approaches to retail globalization, our selected retail firms are all headquartered in the UK. This means they experience similar home market environmental conditions that will inevitably condition their societal embeddedness, for instance through operating within the same 'business system' or 'variety of capitalism' characterized by a liberal market economy with low labor unionization and government intervention as well as financialized forms of firm governance in which the capital markets loom large in affecting their resource allocation and behavior. Such firms have also become

\footnotetext{
3 Our interviews lasted between 40 and 90 minutes and were normally audio-recorded. The subsequent transcription generated in excess of 1,000 A4 pages of text which were then thematically coded independently by two of the research team. To maintain the anonymity of interviewees in our analysis, direct quotes are introduced via an interview number but the relationship to the relevant retail firm case is made explicit.
} 
habituated with a specific and relatively sophisticated customer base that make explicit certain expectations (e.g. regarding delivery, degrees of price competitiveness and 'disposable' fashion), though notably the retail firms in our sample target markedly different customer groups. These factors contribute to a domestic market environment that is fiercely competitive, placing an onus on retail innovation and arguably position UK online retailers at the vanguard of this emerging field. Evidently, the specific nature of the international online fashion retailers in our study offer opportunities for future research in this area to explore other operators emanating from different institutional backgrounds that might go on to exhibit markedly different behaviors to the ones we identify here.

As Table 2 describes, the five case study online retailers cover a variety of retail segments from fast fashion, lifestyle to formal menswear ${ }^{4}$. While the retailers are all headquartered within the UK and international in orientation, they vary in size - from less than $£ 200 \mathrm{~m}$ turnover through to greater than $£ 1.5$ billion in sales. Retailers B, C and D are predominantly 'pure play' online retailers, while retailers $\mathrm{A}$ and $\mathrm{E}$ are omni-channel operators that also operate significant store networks - the former only within its home market. Wholesale sales are particularly important for Retailers E and, a lesser extent, A, and are channeled through both third party store-based and online retailers.

Despite the significant international sales of all five of the online retailers, the extent of their physical infrastructure remains remarkably domestic. Table $\mathbf{3}$ details the limited presence of overseas distribution centers and subsidiary country offices which infer a prevailing centrality of both home market management and physical operations. In the following section, we draw on our interviews to explore these issues.

\footnotetext{
** Tables 2 and 3 about here **
}

\footnotetext{
4 'Fast' fashion is a concept whereby designs from the catwalk are rapidly replicated on the high street in a process facilitated by quick response relationships with the manufacturing base and throughout the supply chain (see Tokatli and Kizilgun, 2009). Meanwhile a 'lifestyle' fashion brand refers to the tailoring of a retail offer closely to the lifestyles of a specific market segment. As such, it embodies symbolic meaning and values for the lifestyle of the particular consumer group and extends the function of the retailer into the lives of consumers. (see Helman and de Chernatony, 1999).
} 


\section{Substituting Physical Presence with Virtual Operations Governed by Societal Embeddedness}

Given Burt et al.'s $(2016 ; 2017)$ recognition of variegated approaches to realizing embeddedness within host markets between retail sectors, it would be logical to assume that even without the demands of constructing appropriate store networks, online fashion retailers would undertake market research to inform the localized adaptation to product ranges (colors and sizes), and in order to vary the tone, medium and content of marketing messages and ensure some degree of 'in-market' presence and relevance. Instead, we identify a predominantly centralized home market approach to both the physical infrastructure of their distribution systems and how they frame their international competition and customers. In our three stage conceptualization, such characteristics are typical of the 'exploring online potential through the lens of societal embeddedness' phase as home market based executives leverage the TNC's virtual network capabilities to establish standardized processes in implementing largely inflexible, homogeneous approaches to new markets. It is to these issues we now turn.

\section{Home Oriented Geographies of Fulfilment}

Table 3 underlines the limited distribution and logistics capability our online fashion retailers operated within host countries, as fulfilment of orders was predominantly undertaken from warehouses situated within the home market. This reflected a concern with prohibitively expensive set up costs of logistics and fulfilment infrastructure outside the UK given the diffusion of international sales across numerous markets rather than the concentration of sales in a few key countries. As global logistics provider, DHL (2017: 8) concedes in a recent report, while there are some advantages to localized fulfilment in the form of quicker shipments over shorter distances, it runs the risk of 'having slow-turning SKUs [stock-keeping units] sitting in inventory everywhere'. Indeed, overseas fashion retailers, even when they are store-based rather than virtual, tend only to invest in extensive logistics facilities relatively late in their expansion within a host country. For example, the Arcadia Group, owner of TopShop and Dorothy Perkins brands (amongst others), is present across 37 overseas markets, yet only in September 2016 did it open its first distribution center 
outside the UK, meaning that every shipment no longer comes through the home market before going overseas (Arcadia, 2017) .

While the argument for centralization might be understood in terms of the avoidance of sunk costs, the efficiency of home market oriented distribution networks was questioned. The geography of international fulfilment was often rather convoluted whereby Asian sourced apparel would be sent to the UK and then sent back to fulfil an online order from Asia. This was common across four of the five retailers in our sample. If we take Retailer D, a formal menswear online merchant as an example, its Merchandising Director admitted:

From the fulfilment perspective, from the customer, anything that is ordered online comes from the UK, wherever you order it from. Even if you want it back in China, it comes from the UK (D1)

Such apparent inefficiencies for Retailer D continued: it operated a successful online business in the US alongside a small number of stores, yet there was a lack of integration between the logistics and fulfilment infrastructure serving the US stores and US online orders. Consequently, a shirt ordered online, if returned to a US store, could not be re-merchandised due to the limited product range on sale within its stores - instead, all returns came back to the UK. As Retailer D's Merchandise Director continued:

Some of these garments are very well-travelled [...] Everything comes back into the UK, but there is some stock that does end up in the retail stores in the US that was never allocated to the retail store. So, if you think about a slim-fit shirt, we will run 35 different SKUs [...] so I end up with stock in the warehouse that essentially I need to send back to the UK because I can't sell it (D1)

Meanwhile, lifestyle fashion Retailer E, which has more international experience and a large store network, developed a Continental European distribution center that complemented its UK-based facility and offered fulfilment of online orders across mainland Europe. Yet, in practice, orders often ended up not being fulfilled strictly by geography but through a 'mix and match' approach depending

\footnotetext{
${ }^{5}$ One significant pure play internet fashion retailer to invest in physical logistics infrastructure is ASOS which, at the time of writing (2018), has made the decision to invest in a second distribution center in the United States at a cost of $£ 31 \mathrm{~m}$ to reduce fulfilment times. This complements its current modestly sized facility that manages only $25 \%$ of US orders, with the remainder dispatched from the UK home market.
} 
which distribution centers had particular products in stock. The Senior Merchandiser acknowledged a common scenario:

If somebody orders three things and one thing is out of stock in the [European] warehouse and one thing is in the UK warehouse, it could split the order and send the two items from [the European warehouse] and one item from the UK (E1)

The variegated regulatory regimes between host markets at times disrupted smooth operation of the supply chain. For example, Retailer D had to comply with US legislation relating to country-of-origin labelling when products were sold in its US stores, but not when sent by online order from the UK. Such labelling requirements were not required in other territories so such labels were typically not added when the merchandise was produced in Asia. This meant that while merchandise was sent to the UK in a condition for dispatch to most markets, the retailer had to then specially sew "made in" labels in the UK prior to dispatch to the US stores:

In the US, everything has to have a "country of origin" back-neck label [...] We don't want to shout about it being from Vietnam or China, as people associate it with lower quality, whereas that's far from the reality. We make sure that those products that come direct from the supplier have that happen to them already [...] our tailoring team sew in the labels before it goes over. (D1)

The complex regulatory infrastructure at the level of the nation state thus has the potential to pose challenges to transnational retailers which vary depending on whether a physical or virtual distribution channel is selected by the consumer within the host market. Nevertheless, these issues were rarely identified by our respondents given the tendency of our sample of online fashion retailers to focus on EU and other psychically proximate markets such as US and Australia rather than states characterized by more divergent regulatory structures.

\section{Centralized Pricing, Ranging and Merchandising from the Home Market}

With greater sales emanating from particular overseas markets, separate country teams were commonly established within retail TNCs, but importantly these typically remained physically located within the home market head office. While failure in international retailing is often known to be related to inappropriate localization, market-specific international pricing and ranging appeared not to 
be a central concern of these retailers. Instead, the international online retailers in our sample undertook decisions from their home market with minimal systematic research into the respective host market retail competition or customer base. The approach that was widely employed was to apply the retailer's domestic price with a simple percentage uplift along with a conversion for currency differences, as the Head of Merchandising for fast fashion Retailer C conceded:

[Pricing is] more controlled by [the Chief Executive Officer] and [Finance Director]: they control the international price in terms of uplift [...] Do we then need to change the straight conversion? [...] We're not that mature as a business [...] because the UK still drives $70 \%$ of our demand $(\mathrm{C} 1)$

Often these approaches were codified in so-called 'equivalency tables' commissioned by the finance departments of the retailers to allow systematic international pricing. As the Product Director of Retailer E, a lifestyle focused and experienced international operator, reflected:

What we try and do is make it simpler to execute. So, we have a look-up table which has all the classes in the business in it, all the UK price points in each of those classes, and then as a US dollar, a Euro, a Danish Krone, a Swedish Krone, a Norwegian Krone, [with] conversion next to it (E2)

The corollary was that online fashion retailers largely ignored regional differences in customer demands and the variegated competitive structure of retail markets. Indeed, industry analyst, Pitney Bowes (2017: 25) recently reflected that frequently online 'retailers don't see a difference between how their value propositions are received by domestic vs. foreign consumers'. Nevertheless, there was some awareness of the shortfalls in employing an easy-to-use yet homogeneous approach. On occasion, arbitrary rules led to prices and ranges that were inappropriate for the specific host market, as the Commercial Director for Retailer A reflected:

By the time you've applied the exchange rate and the [10\%] premium, you might be pricing yourself out of the market (A7)

For those merchandisers located within the UK head office responsible for a particular fledgling international subsidiary, there was a degree of frustration evident in their inability to adjust 
merchandise prices and ranges so they were appropriate for the local consumer - instead, the importance of the home market dictated the overseas merchandise and their price points:

We're a bit handcuffed in terms of the buying teams are over here [in the UK] [...] moved [us] significantly more towards full-price than they would have in the past, which meant it suited [the home market consumer], and it absolutely killed us because we didn't have the ability to cherry-pick some promotional offers (B7)

There was very limited adaptation from-a-distance rather than a focus on benefiting from physical inmarket presence which might enhance strategic localization. Commonly, however, issues of localization were framed by executives simply in terms of the timings of promotions and events rather than a sophisticated understanding of regions and consumers. While our assessment thus far has appraised online TNCs' approaches to variegated cultural and institutional pressures within host markets in terms of ranging, pricing and fulfilment, next we briefly assess another component of territorial embeddedness - sourcing and supply networks.

\section{Approaches to Apparel Sourcing with International Online Fashion Retailing}

Given the home market oriented focus of fulfilment, product ranging and pricing across the online retail TNCs, it is unsurprising that their apparel sourcing networks were not territorially embedded within overseas host markets and instead widely reflected trends discussed within the literature for conventional store-based fashion retailers. That is to say, they typically sourced from Asian countries, albeit with an increasing shift towards more proximate states that balanced the benefit of relatively low labor costs alongside greater responsiveness - for example, Turkey ( $c f$. Tokatli and Kızılgün, 2009) (see Table 3). Retailer A predominantly served middle-aged female consumers and enjoyed long-standing sourcing relationships in northern China, yet it was now seeking to develop sourcing hubs closer to its domestic and pan-European customer base to increase responsiveness, flexibility and to reduce lead times - nevertheless, all merchandise would continue to be dispatched from the home market:

We are developing Turkey as that closer-to-home product area [...] not just being agile on inseason activity, but it also helps our wholesale because we sell our wholesale product after we've bought it. [...] If some of that was in Turkey then we wouldn't have had to have bought 
it [upfront]. I'm not saying we're going to flip, but a little bit of balance like that does help (A4)

Often the predominant sourcing focus on low labor cost Asian countries is indicative of low skilled and precarious job security for workers (Lund-Thomsen and Lindgreen, 2014), yet within our firms there were examples of enduring and significantly upgraded supplier relations. One example was formal menswear focused Retailer D's close sourcing network embeddedness with one highly sophisticated formalwear supplier based in Hong Kong that included the sharing of analytics. This supplier was able to accurately forecast demand across Retailer D's global online and more limited store base to provide a timely supply of merchandise that reduced pressure on the retailer's UK distribution center:

We operate a vendor managed inventory with [our main shirt supplier] [...] We give them all of our data, weekly down to individual store and sales by territory, mail-order, online, and by SKU [...] that goes into their model, and we then, in addition to that, give them a forecast for the season, by line [...] And then they have a huge amount of historical data as well [...] They then forecast that by SKU (D1)

While we observed an overwhelming engagement with global apparel supply networks, fast fashion oriented Retailer $\mathrm{C}$ was exceptional by investing heavily in its network embeddedness with local, UKbased manufacturers. The retailer took advantage of a cluster of clothing manufacturing firms in Leicester and combined this with online analytics relating to consumer demand derived from its web site. It found that it could present a vast range of styles online - far more than any physical network of stores could profitably offer - and then respond to customer demand on those particular lines that proved popular by commissioning further production runs in short order given the geographically proximate sourcing network. This strategy is characteristic of a partial 're-shoring' or 'nearshoring' of clothing production (see Froud et al., 2017; McKinsey, 2018) and is compatible with continued international expansion of the fast fashion retailer for as long as global online orders are fulfilled out of the UK. Yet, when and if this were to change, such sourcing infrastructure may serve to impede internationalization - in many respects 'locking in' the firm to a particular geography and behavior that may not be attractive in the long run (cf. Phelps and Fuller, 2016). 
While the evidence thus far has indicated an emerging online fashion retail sector dominated by an inward-looking societal embeddedness, lacking engagement with the demands of host market consumers, institutions and regulations, there is some indication of a growing concern with territorial embeddedness leading to greater engagement with, and response to, the heterogeneous requirements of national markets and wider supra-national regions. It is to these issues we now turn.

\section{Limited Investment in Territorial Embeddedness: Physical and Relational Engagement with}

\section{Host Markets}

While our international online retailers exhibited behaviors largely governed by inward-looking conceptualizations of societal embeddedness, leading to inflexible, centralized retail 'command-andcontrol', there has been recent limited investment in territorial embeddedness focused on decentralized physical distribution facilities, the development of subsidiary country office functions, as well as some attempts at localized pricing and product ranging. Partly this is indicative of a phased commitment to specific international markets that runs in line with their clear potential for sustainability. These developments are characterized in the second phase of our conceptualization of increasing engagement with host markets - 'exploiting the overseas host market at-a-distance' - and then lead to the third stage, namely 'partial investment in territorial embeddedness through limited host market infrastructure'.

\section{Early Attempts at the Strategic Localization of Pricing and Ranging}

Despite an overwhelming standardization in product ranging and pricing for international markets, some experiments were undertaken in localizing fashion assortments for particular countries as well as regional pricing in response to the local competitor base. However, these were commissioned from the home market and typically met with difficulty. Fast fashion Retailer C, for instance, experimented with a season of dedicated ranges for the Australian market. However, these product lines did not sell well and, perhaps more significantly, ultimately served to reinforce an ethnocentric perspective in advocating home market insights at the expense of localized sensitivity. The Lead Buyer for dresses reflected on the episode: 
We had dedicated designers pulling trends for that market, so there were special collections that we could promote overseas at the right time but it wasn't successful at all [...] We just found that they actually like similar things [as the UK] and we've built up a kind of pattern of trying to understand each market from our own (C7)

The operator also experimented with localized pricing for an overseas market but the complexity involved meant that it backtracked - as its Head of Merchandising recalled:

We've had a go at differential pricing but it coincided with other online pricing issues 12,500 prices that changed in 48 hours - so have put on the back burner for the time being (C5)

Retailer E, a 'lifestyle' merchant with significant international experience, introduced market-specific pricing in Germany but found that the lower price points did not result in sales volume increases, so quickly resorted back to basing it on UK prices, as the Senior Merchandiser reflected:

We did look at price experiments [...] we looked at Germany and we looked at polo-shirts [...] We looked at reducing the prices because we thought the prices were actually too high [... but] it made very little difference to the units, so all we did was lose margin, so we put the price up again (E1)

When pressed, senior management were sanguine about the future development of more appropriate adaptations and the realization of territorially embedded product ranges and prices for variegated host markets over the longer term. Yet, much of the challenge came from the pace of change within the retail firms over such a short period of time - a sentiment somewhat mirrored in Schu and Morshett's (2017) concerns with the 'get-big-fast' approach to international online retail expansion developing quicker than actionable insights into relevant markets. Within such work contexts and organizational micro-politics, there was a degree of ambiguity regarding the appropriate approach, or what priority investments should be. As a result, there was a sense of a gulf between what executives wanted to do and what they were able to achieve within the time window and resources made available. The Senior Merchandiser for Retailer E summarized the predicament experienced by many of the executives within the retailers we interviewed: 
The business has grown massively in four years and there's always so many different [things] you want to go after - new distribution centers or new systems...new processes, new markets, new channels, all these things we've looked at, and it's just the speed at which we can get to it (E1)

This intra-firm context relating to limited material and time-related resources, knowledge and power is inherently relational and has been discussed extensively within economic geography (Bathelt and Glückler, 2005; Faulconbridge, 2017) and also, on occasion, specifically in the context of retailers (Wood and Reynolds, 2011). Yet, such challenges are deepened in the case of our sample of online retail firms as the work practices underpinning successful 'virtual' global operations are unproven, emergent and subject to continued adaptation.

\section{Online Platform Localization and Emerging Investments in Limited Role Subsidiary Country Offices}

Initially our retailers tended to operate a homogeneous 'global' website offering a consistent presentation and product offer for consumers on a worldwide basis although there was localization for the local language and a currency conversion function that would adapt the final price for delivery and taxes in relation to the respective market. Beyond the generation of international sales, such global sites offer the opportunity to identify latent demand from international consumers 'via web analytics in just a matter of minutes' (DHL, 2017: 5). The Director of Merchandising for Retailer D described how a global site acts as a precursor to 'localized' sites if sufficient demand is forthcoming:

So, we operate off a global site, so like a network, a base, a platform that allows us to operate in like 110 territories. We take those sales already - so [...] you can purchase in dollars, pounds or euros, and there's a conversion [...] From that, what we ascertain is [...] what's at the top of the tree, take those [countries], and then we explore and do some [...] customer testing, what's the response rate from those customers, do we think there's an opportunity to grow it? (D1)

Such sites are important in terms of overcoming consumer ignorance and then identifying instances where initial sales performance in a market suggested sufficient potential that justified tailored attention and investment. Of course, generating customer demand is made more challenging given the retailers in our sample tended to be predominantly online-only international operators and 
therefore brand awareness was difficult to communicate. As the Director of E-Commerce for Retailer A, which focused on middle-aged women's fashion, reflected:

[It is] harder internationally, particularly from a direct point of view, because we have tried to cram 25 years of the brand into two years and expected it to happen like that. Obviously, it doesn't - can't just get people to pick up what a brand stands for, its values and what it's famous and good for (A2)

As Table 3 underlines, all retailers in our sample, with the exception of fashion department store, Retailer B, have moved beyond a homogeneous 'global' online site to develop country specific websites. In addition, fast fashion Retailer $\mathrm{C}$ has developed a suite of apps for smartphones internationally, while Retailers D (formal menswear) and E (lifestyle merchant) operate more than 20 country specific localized web sites. It is clear that these more sophisticated tailored apps and web sites tend to be associated with the more experienced international online TNCs and thus situations where international sales levels justify greater levels of capital investment targeted at specific crossborder markets by the retailer.

A rigid adherence to centralized home market decision-making has also been slightly moderated by some development of subsidiary country office functions by Retailers B, C, D and E (see Table 3). These tended to be limited investments within markets that were deemed by senior management to offer opportunities for significant sales and profit momentum ${ }^{6}$. Yet, the dominant approach characteristic of our sample of online retailers was the foundation of subsidiary country offices that identified, targeted and responded to local 'buzz' in a local marketing and public relations sense (cf. Bathelt and Turi, 2011) rather than nodes that prised significant authority and meaningful independence for localized decision-making away from the home market. As such, these were far from the fully-functioning retail subsidiary offices discussed in research focused on store-based expansion (Wood and Reynolds, 2014), instead being thin subsidiary country offices focused on influencing local trends across the media and consumer cultures 'on the ground'.

Online 'buzz' promoted through social media channels is becoming increasingly important for influencing fashion trends as 'today's hottest trends are determined by individual influencers and

\footnotetext{
${ }^{6}$ The one exception to this is Retailer E that operated an extensive international store estate alongside its online capability so was committed to widespread subsidiary country office networks.
} 
consumers rather than by the marketing departments of fashion companies' (McKinsey, 2018: 4; see also Crewe, 2017). Yet senior management sometimes felt marketing the retail brand at-a-distance through virtual proximity needed to be supplemented by geographic proximity in order to manipulate leading fashion influencers ( $c f$. Brydges and Hracs, 2018). For instance, the Head of Merchandising for Retailer C, a fast fashion operator, noted that temporary mobility through business visits by senior management was insufficient as the retailer grew given the need to continuously engage with the fashion press and ensure their trends were published in the right magazines and social media within the US:

The offices at the moment are more marketing and PR driven [...] the offices are out there to keep that momentum going, to keep the talking on the street and in the press and the fashion arena [...] We could get to the stage where we have DCs [Distribution Centers] out in territories, their own product ranges but at the moment those offices are to keep that buzz going and to learn more and feed into us the competition, the trends [...] We are trying to be local in terms of not just a foreign retailer in your arena. We want to be a British fashion retailer [...] but we don't want to be an alien on their high street (C1)

The extent to which these subsidiary country offices - which typically employed less than 20 staff made decisions that departed from the home market strategy remained limited as the locus of control, dominated by perceptions of societal embeddedness, continued to sit with the senior managers based in the UK. Instead, subsidiaries had a largely advisory function, as Retailer E's Senior Merchandiser explained:

We have area managers and territory managers out in the US and in the EU, but [...] you're talking about a handful of people versus what we've got here in [the UK head office] [...] They do have an input, but essentially that decision is predominantly made by the team here in [the UK head office] (E1).

Senior management based in the home market were wary of unleashing subsidiaries to make their own decisions, preferring relatively tight control and monitoring - something reflected in wider studies into TNCs (e.g. Ambos et al., 2010). Partly, this stems from the perceived need to retain a standardized retail brand proposition irrespective of geography. The Product Director for Retailer E presented a typical view from our interviews: 
The trouble is, give an operator autonomy to price anywhere in the world and there's only one direction they're ever going to go in, regardless of what the facts say. So, I think we'd allow ourselves to be informed and influenced by them, but we wouldn't want them taking decisions on price - that would be very dangerous (E2)

\section{Developments toward In-Country and Supra-National Region Fulfilment}

While the degree of investment in physical infrastructure within host countries remained limited,

Table 3 reveals some modest development of fulfilment facilities beyond the home market - by formal menswear Retailer D in the United States (currently for its stores only) and the more experienced international Retailer E across Continental Europe, Hong Kong and the United States (for online and stores). This trend is likely to continue, with Pitney Bowes (2017) concluding in a recent survey of 1,275 retailers that $45 \%$ have either already implemented or are piloting a logistics infrastructure that manages the entire fulfilment process from ordering to final delivery. Such investments offer the potential to become fully integrated in terms of fulfilling customer orders regardless of whether they are online or in-store and will reduce shipping times. Retailer E is the only operator within our sample to exhibit these capabilities in moving towards a single stock pool, rather than one split by channel (online, store, wholesale) - as its Product Director explained:

We used to have e-commerce stock-pool, we had a retail stock-pool, and we had a wholesale stock-pool. A couple of years ago, we put e-commerce and retail together, so that's all in one pick-face now, and then, from the middle of next year, we add wholesale to that as well. The beauty of that is that any wholesale customer anywhere in the world has access to our full inventory, and equally, it means that we're not having to buy stock for wholesale in the hope that a wholesale customer will sell it, because if they don't, we can sell it through one of the other channels. [...] when I say a single pool of stock, it's in each geography (E2)

However, this was an exception. Typically, there were enduring challenges relating to the costs of fulfilment and logistics in host countries - particularly reverse logistics when customers decline a delivered order given the lack of retailer owned warehousing in the host country. Fashion department store, Retailer B noted that the returns rate of some items is sometimes in excess of $50 \%$ as customers order two sizes and return one, which heavily impacts on profitability. These issues were exacerbated in low margin fast fashion, with Retailer B having stopped repurposing some returned low cost apparel, with it instead going straight to clearance to mitigate this reprocessing cost. 


\section{Conclusion - Conceptualizing Dynamic Processes of Territorial Embeddedness in Online}

\section{Fashion Retail}

Our empirical findings contribute to a more nuanced conceptualization of embeddedness within virtual networks. The online business models of our sample of retailers - combined with an attractive 'portable' international retail brand - allow such TNCs to, at least initially in their internationalization, overlook any significant imperative for realizing territorial embeddedness in cultures of consumption or investment within logistical infrastructure in host markets. In stark contrast to economic geography research concerning store-based international retailers (e.g. Burt et al., 2017), our evidence uncovers an overwhelmingly rigid approach dominated by inward-looking conceptualizations of societal embeddedness, with senior management content to be governed by ethnocentric perceptions of the demands of local consumers. These evaluations are founded on decision-making based physically and cognitively in the home market, and an ability - facilitated by virtual network access to overseas consumers - to employ an heuristic approach to retail pricing based on the domestic market and near homogeneous merchandise ranging across geographies. The use of cross-border fulfilment from the home market has meant that in many instances there is no perceived need for any physical presence whatsoever in host markets. A centralized arm's length approach to international retail development is facilitated by a virtual, online business model that is recognized by executives as leading to imperfect international merchandise pricing and ranging. But equally, it involves minimal set up costs which are important in retail firms where the majority of sales originate from the home market and where international sales in any single host market are typically modest.

While acknowledging an overriding approach dominated by societal embeddedness, we identify and thus conceptualize a progressive engagement with the consumer cultural and institutional demands of host markets that comes with increased international retail experience and significant international sales volumes. We evidence this phenomenon in Table 4 by fleshing out in greater detail the three-stage typology outlined in Table 1. We identify increasing localized engagement by our sample of online retailers that comes from experience - ranging from exploring online potential through the lens of societal embeddedness to partial investment in territorial embeddedness through 
limited host market infrastructure. This is becoming apparent particularly in the development of distribution centers closer to key markets and executives' cognizance of a need to influence local fashion 'buzz' within host markets through the use of country head office functions focused on influencing key opinion formers in the fashion world. It is partly suggestive of the limitations of administering retail marketing solely from a virtual network located in the home market and hence the difficulty of achieving the necessary tacit based buzz and generation of network embeddedness in key host markets. Yet, at present, these subsidiary offices are rarely involved in designing or commissioning specialist ranges nor managing tailored pricing and promotions. Instead, such issues typically remain the concern of executives based in the home market, with entrenched societal embeddedness resulting in 'command and control' behaviors. Clearly, this is facilitated by the ease of being a virtual, pure play retailer, though there are drawbacks in terms of the efficiency of 'being there but not present', as came through strongly in our respondents' comments.

** Table 4 about here **

Our work therefore further develops research concerning the nature of contemporary retail globalization (Coe and Wrigley, 2018) but also wider economic geography scholarship that emphasizes the limits of virtual networks in wholly overcoming geographical difference - something established in terms of knowledge transfer and the related need for various forms of mobility and presence (e.g. Brydges and Hracs, 2018b; Faulconbridge, 2017). Online fashion retailers still exist in the 'real' economy in terms of sourcing physical (rather than digital) products, need to achieve 'organizational legitimacy' for merchandise ranges and pricing architecture within regional cultures of consumption, and secure timely competitive physical delivery to customers. It also suggests that territorial embeddedness is not simply a national market and wider regionally-specific phenomena, but equally one that is contingent - heavily dependent on the nature of the merchandise sold, the potential offered by online modes of customer engagement and the maturity of the retail operation within any individual host market. 
Just as processes of embeddedness are known to be ongoing and relational rather than completed at the time of market entry, so it is highly likely that these practices will continue to evolve and therefore our three-fold conceptualization of progressive engagement is likely to be incomplete and demands further exploration in this fast moving sector. As the scale of opportunity within some larger national markets and related supra-national regions becomes proven we hypothesize that additional engagement with localized consumer cultures, national institutions and ultimately greater physical investment in infrastructure and subsidiary-based personnel will become necessary. This will see more appropriate product ranges and price points aligned with a fulfilment system that is more responsive and ultimately more price competitive. While this engagement with the national and supra-national scale will remain significantly below that demanded in store-based expansion, it will and has in some of our observations to date - underlined how local conditions cannot be completely overlooked with virtual retailing.

Central to the gradual process of investing in territorial embeddedness within subsidiaries is a modification of the geography of decision-making and control within the retail TNCs. Departing from the centralized, arm's length organizational configuration that we have observed towards increased physical investment and enhanced authority for fledgling subsidiary country offices means the retailer will need to move from routines and behaviors solely focused on a domestic footing, towards ones that take international contexts seriously. This will require a degree of flexibility on the part of senior retail managers that have historically retained close control of the entire domestic and international businesses. Both the management studies and economic geography literature has recognized the need for TNCs to avoid the perils of such lock-in to entrenched forms of behavior (Fuller and Phelps, 2018) - something that, in these particular firms, will require the selective embracing of sunk costs and the partial reconfiguration of the retail TNC. This process will likely be contested and involve some intra-firm conflict, but is likely to be necessary if online fashion retailers are to become the internationally relevant global businesses their owners envisage and a heterogeneous overseas customer base demands. 


\section{References}

Ambos T. Andersson U. and Birkinshaw J. 2010 What are the consequences of initiative-taking in multinational subsidiaries? Journal of International Business Studies 41(7):1099-118. doi:10.1057/jibs.2010.19

Appel, A. 2016 Embeddedness and the (re)making of retail space in the realm of multichannel retailing: The case of Migros Sanal market in Turkey. Geografiska Annaler: Series B, Human Geography 98(1):55-69. doi:10.1111/geob.12089

Arcadia 2017 Transport and Logistics. Accessed online at https://www.arcadiagroup.co.uk/fashionfootprint/our-environment/transport

Bathelt H and Glückler J. 2005. Resources in economic geography: from substantive concepts towards a relational perspective. Environment and Planning A 37(9):1545-1563. doi: $10.1068 / \mathrm{a} 37109$

Bathelt $\mathrm{H}$ and Turi P. 2011 Local, global and virtual buzz: The importance of face-to-face contact in economic interaction and possibilities to go beyond. Geoforum 42(5):520-529. doi: 10.1016/j.geoforum.2011.04.007

Birkin M, Clarke G and Clarke M. 2017 Retail Location Planning in an Era of Multi-Channel Growth. London: Routledge.

Bloom JD and Hinrichs CC. 2017 The long reach of lean retailing: Firm embeddedness and WalMart's implementation of local produce sourcing in the US. Environment and Planning A 49(1):168-185. doi: 10.1177/0308518x16663207

Brydges T and Hracs BJ. 2018a Consuming Canada: How fashion firms leverage the landscape to create and communicate brand identities, distinction and values. Geoforum 90: 108-118. doi: 10.1016/j.geoforum.2018.01.022

Brydges T and Hracs BJ. 2018b The locational choices and interregional mobilities of creative entrepreneurs within Canada's fashion system. Regional Studies doi: $10.1080 / 00343404.2018 .1478410$ 
Burt S Coe NM and Davies K. 2019 A tactical retreat? Conceptualising the dynamics of European grocery retail divestment from East Asia. International Business Review 28(1):177-189. doi:10.1016/j.ibusrev.2018.05.010

Burt S Johansson U and Dawson J. 2016 International retailing as embedded business models. Journal of Economic Geography 16(3):715-747. doi:10.1093/jeg/lbv008

Burt S Johansson U and Dawson J. 2017 Dissecting embeddedness in international retailing. Journal of Economic Geography 17(3):685-707. doi:10.1093/jeg/lbw045

Clark G. 1998 Stylized facts and close dialogue: methodology in economic geography. Annals of the Association of American Geographers 88(1):73-87. doi:10.1111/1467-8306.00085

Coe NM and Lee Y-S. 2013 We've learnt how to be local': the deepening territorial embeddedness of Samsung-Tesco in South Korea. Journal of Economic Geography 13(2):327-356. doi:10.1093/jeg/lbs057

Coe NM, Lee Y-S, Wood S. 2017 Conceptualising contemporary retail divestment: Tesco's departure from South Korea. Environment and Planning A 49(12):2739-2761 doi: $10.1177 / 0308518 \times 17733265$

Coe NM and Wrigley N. 2018 Towards new economic geographies of retail globalization. In Clark GL, Feldman MP, Gertler MS eds The New Oxford Handbook of Economic Geography. Oxford: Oxford University Press 292-316.

Crewe L. 2013 When virtual and material worlds collide: Democratic fashion in the digital age. Environment and Planning A 45(4): 760-780. doi:10.1068/a4546

Crewe L. 2016 Placing fashion: Art, space, display and the building of luxury fashion markets through retail design. Progress in Human Geography 40(4):511-529. doi:10.1177/0309132515580815

Crewe L. 2017 The Geographies of Fashion, London, UK: Bloomsbury.

Currah A and Wrigley N. 2004 Networks of organizational learning and adaptation in retail TNCs. Global Networks 4(1):1-23. doi:10.1111/j.1471-0374.2004.00078.x 
Dales A Coe M and Hess M. 2018 Variegated national retail markets: negotiating transformation through regulation in Malaysia and Thailand. Economic Geography doi:10.1080/00130095.2018.1476060

Dawson J Mukoyama M 2014 Recent developments in retail internationalization. In Dawson J Mukoyama M eds Global Strategies in Retailing: Asian and European Experiences. London: Routledge 5-36.

Deloitte 2018 Global Powers of Retailing 2018. Deloitte Touche Tohmatsu Limited, accessed at https://www2.deloitte.com/uk/en/pages/consumer-business/articles/global-powers-ofretailing.html

DHL 2017 The $21^{\text {st }}$ Century Spice Trade. A Guide to the Cross-Border E-Commerce Opportunity. Accessed at http://www.dhl.com/content/dam/downloads/g0/press/publication/g0 dhl express cross border ecommerce_21st_century_spice_trade.pdf

Durand C and Wrigley N. 2009 Institutional and economic determinants of transnational retailer expansion and performance: a comparative analysis of Wal-Mart and Carrefour. Environment and Planning A 41(7):1534-1555. doi:10.1068/a4137

Faulconbridge JR. 2017. Relational geographies of knowledge and innovation. In H. Bathelt, P. Cohendet, S. Henn \& L. Simon eds The Elgar Companion to Innovation and Knowledge Creation: Edward Elgar 671-684

Foster C and Graham M. 2017 Reconsidering the role of the digital in global production networks. Global Networks 17(1):68-88. doi:10.1111/glob.12142

Frasquet M Dawson J Calderón H and Fayos T. 2018 Integrating embeddedness with dynamic capabilities in the internationalisation of fashion retailers. International Business Review 27(4): 904-914. doi:10.1016/j.ibusrev.2018.02.002

Froud J Hayes S Wei, H and Williams K. 2017 Coming Back? Capability and Precarity in UK Textiles and Apparel. A report funded by the British Cotton Growers' Association Work People's Collection Fund: Alliance Manchester Business School \& School of Materials, University of Manchester. 
Fuller C and Phelps N. 2018 Revisiting the multinational enterprise in global production networks. Journal of Economic Geography 18(1):139-61. doi:10.1093/jeg/lbx024

Helman D and de Chernatony L. 1999 Exploring the development of lifestyle retail brands. Service Industries Journal 19(2):49-68.

Hess M. 2004. 'Spatial' relationships? Towards a reconceptualization of embeddedness. Progress in Human Geography 28(2):165-186. doi:10.1191/0309132504ph479oa

Jansson J and Power D. 2010 Fashioning a global city: global city brand channels in the fashion and design industries. Regional Studies 44(7): 889-904. doi:10.1080/00343400903401584

Jones A and Murphy JT. 2011 Theorizing practice in economic geography: Foundations, challenges, and possibilities. Progress in Human Geography 35(3): 366-392. doi:10.1177/0309132510375585

Leslie D and Brail S. (2011) The productive role of 'quality of place': a case study of fashion designers in Toronto. Environment and Planning A 43(12): 2900-2917. doi:10.1068/a43473

Liu S Perry P Moore C and Warnaby G. 2016 The standardization-localization dilemma of brand communications for luxury fashion retailers' internationalization into China. Journal of Business Research 69(1):357-364. doi:10.1016/j.jbusres.2015.08.008

Lowe M and Wrigley N. 2010 The 'continuously morphing' retail TNC during market entry: interpreting Tesco's expansion into the USA. Economic Geography 86(4):381-408. doi:10.1111/j.1944-8287.2010.01083.x

Lund-Thomsen P. and Lindgreen A. 2014 Corporate social responsibility in global value chains: where are we now and where are we going? Journal of Business Ethics 123(1):11-22. doi: $10.1007 / \mathrm{s} 10551-013-1796-\mathrm{x}$

McKinsey \& Co. 2018 Is Apparel Manufacturing Coming Home? Nearshoring, Automation, and Sustainability - Establishing a Demand-Focused Apparel Value Chain. McKinsey Apparel, Fashion \& Luxury Group October 2018

Meyer K Mudambi, R and Narula R 2011 Multinational enterprises and local contexts: the opportunities and challenges of multiple embeddedness. Journal of Management Studies 48(2):235-52. doi:10.1111/j.1467-6486.2010.00968.x 
Molloy M and Larner W. 2013 Fashioning Globalisation: New Zealand Design, Working Women and the Cultural Economy: John Wiley \& Sons.

Phelps NA and Fuller C 2016 Inertia and change in multinational enterprise subsidiary capabilities: an evolutionary economic geography framework. Journal of Economic Geography 16(1):109-30. doi:10.1093/jeg/lbv002

Pike A. 2013 Economic geographies of brands and branding. Economic Geography 89(4): 317-339. doi:10.1111/ecge.12017

Pitney Bowes 2017 Evolution at Home Revolution Abroad. The 2017 Global Ecommerce Report, Pitney Bowes Inc., 3001 Summer Street, Stamford, CT 06926-0700

Schu M. 2017 Online Growth Options for Retailers. Three Essays on Domestic and International Growth Strategies with Online Retailing: Springer Gabler.

Schu M Morschett D and Swoboda B. 2016 Internationalization speed of online retailers: a resourcebased perspective on the influence factors. Management International Review 56(5): 733-757. doi:10.1007/s11575-016-0279-6

Schu M and Morschett D. 2017. Foreign market selection of online retailers - A path-dependent perspective on influence factors. International Business Review 26(4):710-723. doi:10.1016/j.ibusrev.2017.01.001

Statista 2018 eCommerce Report 2018, September 2018. Accessed at https://www.statista.com on 24 October 2018.

Tokatli N. 2015 Single-firm case studies in economic geography: some methodological reflections on the case of Zara. Journal of Economic Geography 15(3):631-647. doi:10.1093/jeg/lbu013

Tokatli N and Kizilgun O. 2009 From manufacturing garments for ready-to-wear to designing collections for fast fashion: evidence from Turkey. Environment and Planning A 41(1):146-62. doi:10.1068/a4081

Treadgold A and Reynolds J. 2016 Navigating the New Retail Landscape: A Guide for Business Leaders, Oxford, UK: Oxford University Press. 
Wang JJ and Xiao Z. 2015 Co-evolution between etailing and parcel express industry and its geographical imprints: The case of China. Journal of Transport Geography 46:20-34. doi:10.1016/j.jtrangeo.2015.05.005

Wang Y and Coe NM 2017 Power dynamics, supply network restructuring and modernised retailing in China: a comparison of two food staples. Tijdschrift voor Economische en Sociale Geografie 109(3):386-401. doi:10.1111/tesg.12281

Weller S. 2007 Fashion as viscous knowledge: fashion's role in shaping trans-national garment production. Journal of Economic Geography 7(1): 39-66. doi:10.1093/jeg/lb1015

Wood S Coe NM and Wrigley N. 2016 Multi-scalar localization and capability transference: exploring embeddedness in the Asian retail expansion of Tesco. Regional Studies 50(3):475-495. doi:10.1080/00343404.2014.926317

Wood, S., Reynolds, J., 2011. The intrafirm context of retail expansion planning. Environment and Planning A 43(10):2468-2491. doi: 10.1068/A43503

Wood S and Reynolds J. 2012. Managing communities and managing knowledge: strategic decision making and store network investment within retail multinationals. Journal of Economic Geography 12(2):539-565. doi:10.1093/jeg/lbr038

Wood S and Reynolds J. 2014 Establishing territorial embeddedness within retail transnational corporation (TNC) expansion: the contribution of store development departments. Regional Studies 48(8):1371-1390. doi:10.1080/00343404.2012.701731

Wrigley N. 2000 The globalization of retail capital: themes for economic geography. In: Clark GL, Feldman MP and Gertler MS (eds) The Oxford Handbook of Economic Geography. New York and Oxford: Oxford University Press, 292-313.

Wrigley N, Coe NM and Currah A. 2005 Globalizing retail: conceptualizing the distribution-based transnational corporation (TNC). Progress in Human Geography 29(4):437-457. doi:10.1191/0309132505ph559oa

Wrigley N and Currah A. 2006 Globalizing retail and the 'new e-conomy': The organizational challenge of e-commerce for the retail TNCs. Geoforum 37(3):340-351. doi:10.1016/j.geoforum.2005.06.003 
Table 1: Conceptual framework for charting the evolution of online retail TNC embeddedness

\begin{tabular}{|c|c|c|c|c|c|}
\hline \multirow{2}{*}{$\begin{array}{l}\text { Degree of international } \\
\text { commitment to, and } \\
\text { embeddedness within, } \\
\text { host markets }\end{array}$} & \multirow{2}{*}{ Embeddedness processes } & \multicolumn{4}{|c|}{ Engagement with the host market } \\
\hline & & $\begin{array}{l}\text { Web site and } \\
\text { country-specific } \\
\text { marketing }\end{array}$ & $\begin{array}{c}\text { Investment in } \\
\text { physical } \\
\text { infrastructure and } \\
\text { personnel } \\
\end{array}$ & $\begin{array}{l}\text { Localized pricing } \\
\text { and product } \\
\text { ranging }\end{array}$ & $\begin{array}{l}\text { Decision-making } \\
\text { authority of } \\
\text { subsidiary }\end{array}$ \\
\hline $\begin{array}{l}\text { Exploring online potential } \\
\text { from the home market }\end{array}$ & $\begin{array}{l}\text { Societal embeddedness predominates } \\
\text { with very low territorial } \\
\text { embeddedness. Network } \\
\text { embeddedness facilitates overseas } \\
\text { (virtual presence) but remains low in } \\
\text { host countries themselves. }\end{array}$ & Low & Low & Low & Low \\
\hline $\begin{array}{l}\text { Exploiting the overseas } \\
\text { host market at-a-distance }\end{array}$ & $\begin{array}{l}\text { Societal embeddedness remains high. } \\
\text { Territorial embeddedness remains low } \\
\text { but with a slight increase due to some } \\
\text { strategic localization in key markets. } \\
\text { Network embeddedness facilitates } \\
\text { overseas (virtual presence) but is } \\
\text { modest within host markets. }\end{array}$ & Low-Medium & Low & Low & $\begin{array}{l}\text { Low but some } \\
\text { decentralization } \\
\text { apparent }\end{array}$ \\
\hline $\begin{array}{l}\text { Partial investment in } \\
\text { territorial embeddedness } \\
\text { through limited host } \\
\text { market infrastructure }\end{array}$ & $\begin{array}{l}\text { Growing investment in localized } \\
\text { personnel and infrastructure sees some } \\
\text { realization of territorial embeddedness } \\
\text { in larger host markets. However, } \\
\text { senior management retain a strong } \\
\text { sense of societal embeddedness which } \\
\text { limits the degree of decentralization of } \\
\text { authority to subsidiaries. Growing } \\
\text { network embeddedness, with logistics } \\
\text { partners in key markets for example. }\end{array}$ & $\begin{array}{l}\text { Medium - but } \\
\text { growing }\end{array}$ & $\begin{array}{l}\text { Low - Medium but } \\
\text { growing }\end{array}$ & $\begin{array}{l}\text { Low - Medium but } \\
\text { growing }\end{array}$ & Low-Medium \\
\hline
\end{tabular}


Table 2: Key characteristics of the case study international online fashion retailers

\begin{tabular}{|c|c|c|c|c|c|}
\hline & Retailer A & Retailer B & Retailer C & Retailer D & Retailer E \\
\hline Retail sector & $\begin{array}{l}\text { Fashion - middle age } \\
\text { focus }\end{array}$ & $\begin{array}{l}\text { Fashion oriented } \\
\text { department store - all } \\
\text { age groups }\end{array}$ & $\begin{array}{l}\text { Fast fashion - } \\
\text { teenagers, } 20- \\
\text { something focus }\end{array}$ & $\begin{array}{l}\text { Formal fashion retailer - } \\
\text { menswear }\end{array}$ & $\begin{array}{l}\text { Lifestyle fashion } \\
\text { orientation - } 20 \text { - } \\
\text { something - middle age } \\
\text { focus }\end{array}$ \\
\hline Retail presence & $\begin{array}{l}\text { Online, physical } \\
\text { stores, wholesale }\end{array}$ & Online only & $\begin{array}{l}\text { Online, through third } \\
\text { parties }\end{array}$ & $\begin{array}{l}\text { Predominantly mail } \\
\text { order and online. A } \\
\text { modest physical store } \\
\text { portfolio in high profile } \\
\text { locations }\end{array}$ & $\begin{array}{l}\text { Online, physical stores, } \\
\text { wholesale, concessions }\end{array}$ \\
\hline Fascia & Single fascia & Multi-fascia & Multi-fascia & Single fascia & Single fascia \\
\hline Head office & Midlands, UK & Northern England, UK & Northern England, UK & London, England, UK & Southern England, UK \\
\hline Sales & $>£ 100 \mathrm{~m}$ sales & $>£ 1.5$ billion sales & $>£ 200 \mathrm{~m}$ sales & $>£ 200 \mathrm{~m}$ & $>£ 700 \mathrm{~m}$ \\
\hline $\begin{array}{l}\text { Wholesale sales } \text { e.g. } \\
\text { through department } \\
\text { stores or other online } \\
\text { retailers (e.g. } \\
\text { Amazon) }\end{array}$ & $\begin{array}{l}\text { Yes - domestic and } \\
\text { international }\end{array}$ & No & No & No & $\begin{array}{l}\text { Yes - domestic and } \\
\text { international }\end{array}$ \\
\hline $\begin{array}{l}\text { Online sales (as \% of } \\
\text { total) [est.] }\end{array}$ & $\begin{array}{l}\text { circa } 35 \% \text { of retail } \\
\text { sales }\end{array}$ & $\begin{array}{l}\text { circa } 100 \% \text { of retail } \\
\text { sales }\end{array}$ & $\begin{array}{l}\text { circa } 100 \% \text { of retail } \\
\text { sales }\end{array}$ & circa $70 \%$ of retail sales & circa $25 \%$ of retail sales \\
\hline
\end{tabular}


Table 3: International operations of the case study online fashion retailers

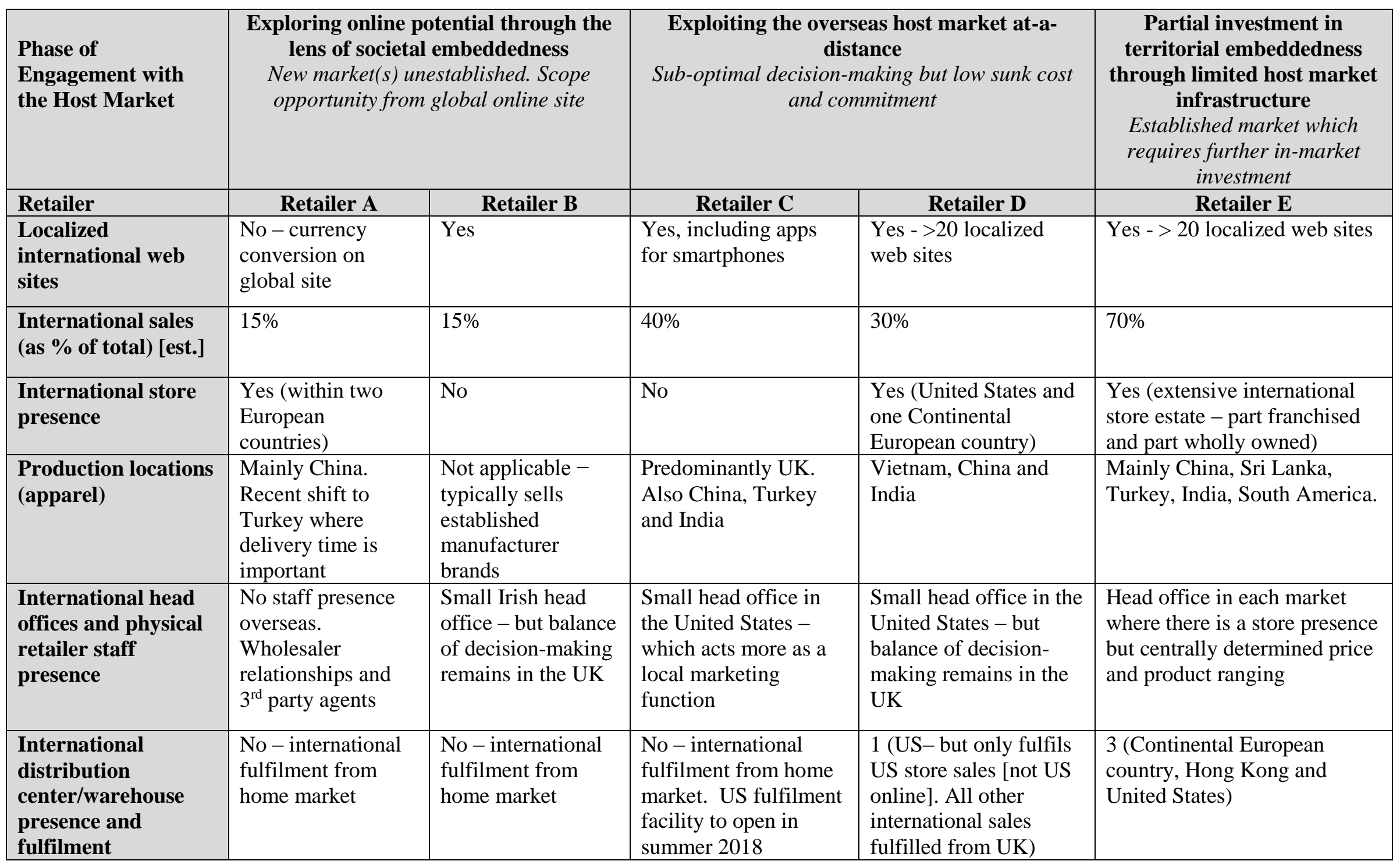


Table 4: Three stage progression in engagement with host markets in online fashion retailing

\begin{tabular}{|c|c|c|c|c|c|}
\hline \multirow{2}{*}{$\begin{array}{l}\text { Degree of international } \\
\text { commitment to, and } \\
\text { embeddedness within, } \\
\text { host markets }\end{array}$} & \multirow[b]{2}{*}{$\begin{array}{l}\text { Example } \\
\text { retailers }\end{array}$} & \multicolumn{4}{|c|}{$\begin{array}{l}\text { Engagement with the host market } \\
\end{array}$} \\
\hline & & $\begin{array}{l}\text { Web site and } \\
\text { country-specific } \\
\text { marketing }\end{array}$ & $\begin{array}{l}\text { Overseas physical } \\
\text { infrastructure and } \\
\text { personnel }\end{array}$ & $\begin{array}{l}\text { Localized pricing and } \\
\text { merchandise ranging }\end{array}$ & $\begin{array}{l}\text { Decision-making } \\
\text { authority of subsidiary }\end{array}$ \\
\hline $\begin{array}{l}\text { Exploring online } \\
\text { potential through the } \\
\text { lens of societal } \\
\text { embeddedness - New } \\
\text { market(s) unestablished. } \\
\text { Scope opportunity from } \\
\text { global online site }\end{array}$ & $A, B$ & $\begin{array}{l}\text { Global ['.com'] site } \\
\text { with currency } \\
\text { conversion. Minimal } \\
\text { country-specific } \\
\text { marketing }\end{array}$ & $\begin{array}{l}\text { None }- \text { Fulfilment from } \\
\text { home market }\end{array}$ & $\begin{array}{l}\text { Standardized pricing } \\
\text { and merchandise } \\
\text { ranging with uplift and } \\
\text { currency conversion }\end{array}$ & $\begin{array}{l}\text { None. Absolute authority } \\
\text { of home market based } \\
\text { executives - no } \\
\text { decentralization of power }\end{array}$ \\
\hline $\begin{array}{l}\text { Exploiting the overseas } \\
\text { host market at-a- } \\
\text { distance - Sub-optimal } \\
\text { decision-making but low } \\
\text { sunk cost and } \\
\text { commitment. Some } \\
\text { recognition of variegation } \\
\text { in market demands }\end{array}$ & $\mathrm{C}, \mathrm{D}$ & $\begin{array}{l}\text { Country-specific sites } \\
\text { but minimal range } \\
\text { editing for host } \\
\text { market. Social media } \\
\text { presence and } \\
\text { promotion }\end{array}$ & $\begin{array}{l}\text { Partial - Subsidiary } \\
\text { country office established } \\
\text { focused on marketing and } \\
\text { promotion in key markets. } \\
\text { However, typically } \\
\text { fulfilment from home } \\
\text { market }\end{array}$ & $\begin{array}{l}\text { Predominantly } \\
\text { standardized pricing } \\
\text { and ranging }\end{array}$ & $\begin{array}{l}\text { Minimal. Predominant } \\
\text { authority of home market } \\
\text { based executives - } \\
\text { minimal decentralization of } \\
\text { power to subsidiary despite } \\
\text { some possible physical } \\
\text { presence in the market }\end{array}$ \\
\hline $\begin{array}{l}\text { Partial investment in } \\
\text { territorial } \\
\text { embeddedness through } \\
\text { limited host market } \\
\text { infrastructure - } \\
\text { Established market which } \\
\text { requires further in-market } \\
\text { investment }\end{array}$ & $\mathrm{E}$ & $\begin{array}{l}\text { Country specific sites. } \\
\text { Some range and price } \\
\text { localization. } \\
\text { Experimentation with } \\
\text { apps for host market. } \\
\text { Tailored marketing } \\
\text { capabilities developed }\end{array}$ & $\begin{array}{l}\text { Yes - Distribution center } \\
\text { and subsidiary country } \\
\text { office development. } \\
\text { Fulfilment from host } \\
\text { market/wider } \\
\text { supranational regions. } \\
\text { Physical store } \\
\text { development becomes } \\
\text { realistic }\end{array}$ & $\begin{array}{l}\text { Some limited } \\
\text { experimentation with } \\
\text { variation in pricing } \\
\text { and ranging. Higher if } \\
\text { store network } \\
\text { developed }\end{array}$ & $\begin{array}{l}\text { Minimal but increasing. } \\
\text { Influence of home market } \\
\text { in majority of operations } \\
\text { but some decentralization } \\
\text { of marketing and } \\
\text { administrative functions to } \\
\text { the subsidiary }\end{array}$ \\
\hline
\end{tabular}

NB. Given the variation in the maturity of retailer presence between numerous new host markets, this represents a generalization of the trends observed. 